Please quote as: Ebner, W.; Leimeister, J. M.; Bretschneider, U. \& Krcmar, H. (2008): Leveraging the wisdom of crowds: Designing an IT-supported ideas competition for an ERP software company. In: Hawai'i International Conference on System Sciences (HICSS) 2008, Big Island, Hawaii. 


\title{
Leveraging the Wisdom of Crowds: Designing an IT-supported Ideas Competition for an ERP Software Company
}

\author{
Winfried Ebner, Marco Leimeister, Ulrich Bretschneider and Helmut Krcmar \\ Technische Universität München, Chair for Information Systems (I17), Boltzmannstraße 3 \\ D - 85748 Garching, Germany, Phone: +49 (89) 289-1 9505 \\ E-Mail: \{ebner; leimeister; bretschneider; krcmar\}@in.tum.de
}

\begin{abstract}
"Crowdsourcing" is currently one of the most discussed key words within the open innovation community. The major question for both research and business is how to find and lever the enormous potential of the "collective brain". This research in progress paper provides an approach for finding and leveraging innovations for an ERP Software company among its user base. This is done by designing an IT-supported ideas competition within the SAP UCC (University Competence Center) User Group to use the potentials of the collective intelligence of this crowd. The German SAP UCC User Group consists of about 60,000 people (lecturers and students) using SAP Software for educational purposes. The practical problem is twofold: On the one hand, there is not much activity yet in this community. On the other hand, SAP has not tried to systematically address this highly educated group for idea generation or innovation development so far. Therefore, the objective of this research is to generate innovations, process and product ideas for SAP Research and Development through an IT-supported ideas competition among the SAP UCC Community. Furthermore, the concept aims at providing an interface to SAP Human Resources processes in order to identify the most promising students in this VC. This paper follows an Action Research Approach. It is focusing on the diagnosing and action planning phase to develop an integrated concept of the ideas competition within the VC.
\end{abstract}

\section{Introduction}

\subsection{Potential of Wisdom of Crowds and Open Innovation}

"Large Groups of people are smarter than an elite few, no matter how brilliant - better at solving problems, fostering innovation, coming to wise decisions, even predicting the future."
Surowiecki's bestseller "The Wisdom of Crowds" underlines the potential of the new paradigm companies are facing nowadays: Open Innovations. Traditionally, the research and development departments are the main driver of a company's innovations. Now, the tendency to open up to other resources of innovations becomes more and more important (e.g., employees, suppliers or universities) [29]. Jeff Howe condenses this new approach of gaining innovation using the phrase "Crowdsourcing". He describes this new phenomenon as "everyday people using their spare cycles to create content, solve problems, even do corporate R\&D” [14].

Literature describes the integration of customers as one of the biggest resource for external innovations (cp. [36]). Customer integration is a mode of value creation in which customers are taking part in both operational and innovational value creating activities. These activities used to be seen as the domain of the firm (cp. [27], [23] \& [32]). As a result, the closed innovation paradigm became obsolete in the 1990s due to four erosion factors [4]:

- The increased availability and mobility of skilled technology workers

- The expansion of the venture capital market

- External options for unused technologies (sitting on the development shelf)

- The increased supply of highly capable external suppliers.

Henry Chesbrough illustrates the new paradigm of open innovation in the context of industrial research and development within figure 1 (see next page). There are two paradigms underlying: Firstly, Crowdsourcing does open the company's innovation funnel - the scope for screening ideas. Therefore, the company gains more ideas for innovations. Secondly, 'We is smarter than me' as the basic assumption of open innovation leads to a better selection of ideas and a better development of innovations (cp. [20], [11]). 


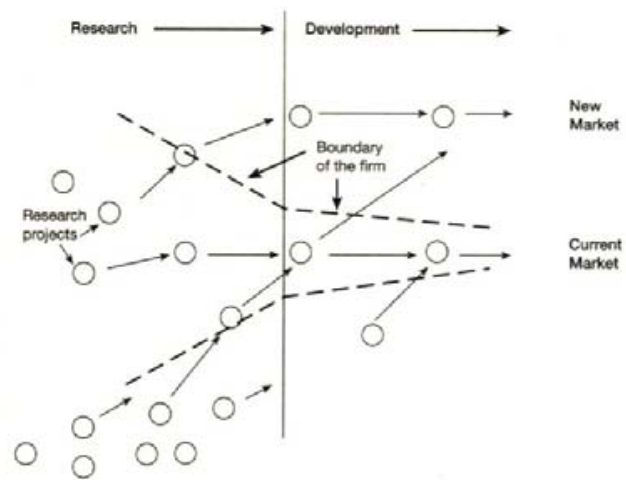

Figure 1: Open Innovation Paradigm for Managing Industrial R\&D

(Source: [4])

Literature shows some useful tools to overcome firms' traditional boundaries (cp. [9], [23] \& [34]). Toolkits for user innovation are an emerging alternative approach in which manufacturers actually abandon the attempt to understand user needs in detail in favour of transferring need-related aspects of product and service development to users themselves.

However, existing VCs as a 'natural' aggregation of (potential) customers can also serve as profound basis for the leveraging of innovative ideas. One of the possible tools within a VC - the IT-supported ideas competition - is not systematically addressed in research yet (cp. [7] \& [37]).

\subsection{Structure of the paper}

The paper is organised as follows: This section ends with a description of the project background. The main stakeholders with impact on the success of the ideas competition are described and related to each other. Section 2 presents a literature review with the theoretical background for both innovations connected to communities and ideas competition. In section 3, the motivational structure of all stakeholders is analysed and an integrated concept of the ideas competition is elaborated. Section 4 provides first insights on the still ongoing ideas competition. The final section 5 summarises the findings as well as the implications and gives an outlook for future research.

\subsection{Project Background}

The SAP University Competence Centers (UCC) of both the Technische Universität München (TUM) and Otto-von-GuerickeUniversität Magdeburg offer an education service, providing SAP systems for institutions of higher education and vocational schools. The UCC meets the special requirements of lecturers using SAP systems in teaching and education [28].

Especially two issues are addressed: Firstly, the core of the support is application service provision (ASP), which includes hardware, installation, maintenance, backup and technical support. Secondly, the UCC provides "Education Specific Services" such as application support, train the trainer courses, teaching cases and teaching notes.

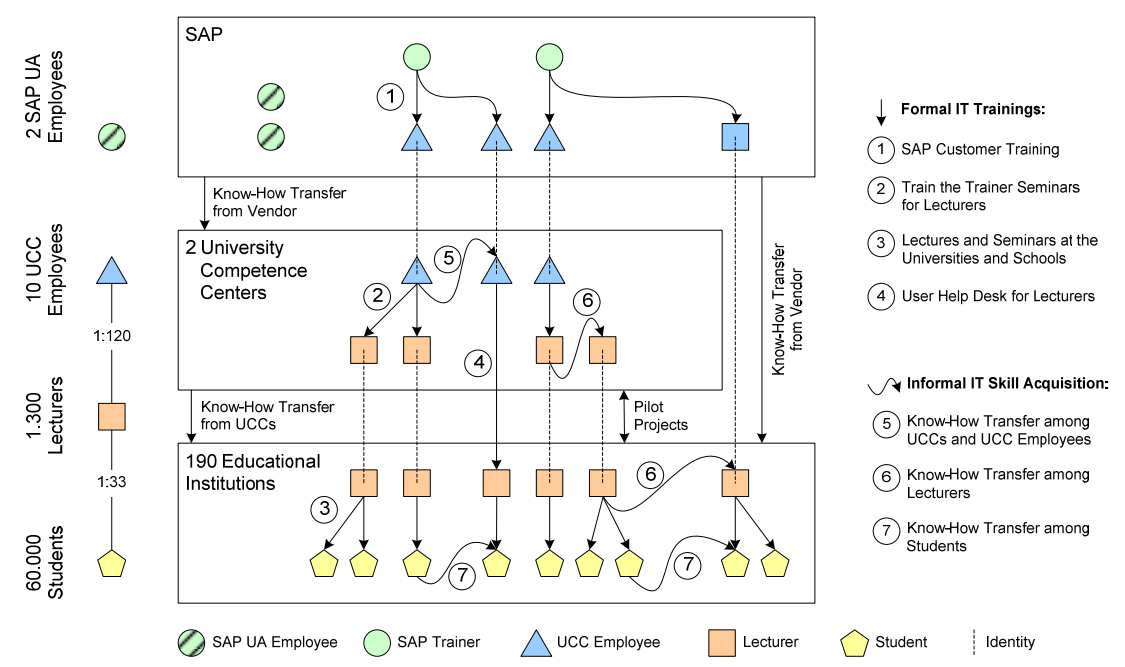

Figure 2: Qualification Concept and stakeholders of SAP UCC Program (Source: Adapted from [22]) 
Figure 2 illustrates the different stakeholders and the qualification concept of the UCC User Group.

The total SAP UCC User Group Community surpasses 60,000 users, of which most are students. Important for the concept of the ideas competition is the two-tier organisation of the UCC Program. As shown in figure 2, the University Competence Centers train the trainers (see (2), while the trainers/lecturers do have the direct contact with university students, e.g., during an ERP-seminar (3). In promoting the idea of an ideas competition, the lecturers play an important role in terms of motivation and support of the students. These circumstances have been taken in consideration while developing the concept of the ideas competition.

\section{Theoretical Background}

This research is designed as an explorative study. As the research object of an "ideas competition" is new and hardly investigated, general theories about the research object do not exist yet. Stating and validating hypotheses purely deduced from theory, common in empirical-analytical research designs, cannot be applied here. Due to this approach, this research does not fit classic positivist scientific standards (e.g., falsification / verification of hypotheses). In addition, the external validity of potential results is low and the transfer of results to other domains is often hardly possible. According to Ulrich, explorative research starts „(...) in practice, is focused on analysing the context of use and ends in practice" [33]. The intention of this research is firstly to design reality, following the tradition of the action research method [19, 26].

\subsection{Innovations and Communities}

In order to understand the interplay of Innovations and Community, we use the stage model of innovation by Tidd [31]. Figure 3 depicts in which phases of the innovation process communities are most likely to be helpful:

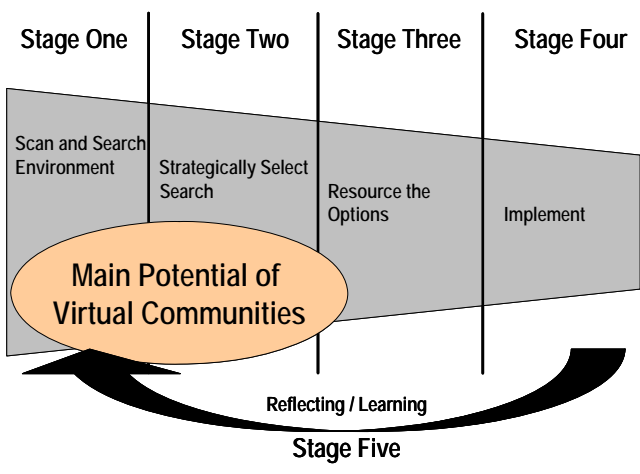

Figure 3: Process of innovation management and potential support of VCs

(Source: Adapted from [31])

Knowing the potential and possibilities of VCs, it is probable that the main support of VCs is taking place within the first two stages ("Scan and Search Environment" and "Strategically Select Search") of the innovation management process. It is also conceivable to use VCs for the reflection and learning phase (Stage Five). Crowdsourcing as described in section 1.1 tries to lever all five stages of the innovation management process. Therefore, these stages should be addressed by other organisational options or a connection between internal and external innovations of a firm [4].

The importance of Community Building as research topic has risen through the development of the World Wide Web and the ongoing virtualisation [21]. Starting with the economic perspective of Hagel/Armstrong [12], this area has been reflected scientifically by multiple viewpoints, e.g., business, sociology and psychology (cp. [1], [2], [3], [5], [8], [15], [18] \& [24]). These developments lead to a heterogenic and partly specific body of knowledge within the research community. However, in-depth research in virtual community building for nurturing innovations has not been accomplished yet (cp. [35]).

For the purpose of this research, we are using a multidisciplinary approach to define "Virtual Community (VC)”. According to Preece, “(...) an online community consist of:

- People, who interact socially as they strive to satisfy their own needs or perform special roles, such as leading or moderating.

- A shared purpose, such as an interest, need, information exchange, or service that provides a reason for the community. 
- Policies, in the form of tacit assumptions, rituals, protocols, rules, and laws that guide people's interactions.

- Computer systems, to support and mediate social interaction and facilitate a sense of togetherness” [24].

According to this definition, the German SAP UCC User Group is a large Virtual Community with great resources for leveraging innovative ideas. We are keeping these four criteria in mind while discussing the occurrence and characteristics of ideas competitions in the following section.

\subsection{Ideas Competition \\ 2.2.1 Occurrence}

As described in the last section, communities mainly support the innovation process in the early stages. Therefore, the ideas competition is not an innovation by definition as the sourcing and the implementation of the idea has not been achieved by a single competition of ideas (cp. figure 3). Although there is not much research done in the field of ideas competition, this instrument is often used in practice to generate ideas. The findings of a literature review were limited to announcements or documentations of ideas competitions, especially in the field of architecture (cp. [10], [13], [25] \& [30]). Therefore, a web-based search tried to identify current or recently finished ideas competitions of the last 2 years. Searching for the term "Ideas Competition" via Google leads to the overwhelming amount of 76.000.000 hits. The examined competitions for the analyses were selected by the following criteria: Topic (New product development), accessibility of information (e.g., more than just an announcement) and actuality (conducted since 2005).

Table 1 shows a selection of the results present ideas competitions for students:

\begin{tabular}{|c|c|}
\hline $\begin{array}{l}\text { Organizer: Name of Competition } \\
\text { [Website] }\end{array}$ & Topic \\
\hline $\begin{array}{l}\text { IBM: Global Innovation Jam } \\
\text { [http://www.globalinnovationjam.com/ } \\
\text { get_started2006/] }\end{array}$ & $\begin{array}{l}\text { InnovationJam is not only just a large on-line brainstorm. The Jam's goal is to move } \\
\text { beyond simple invention and idea generation. IBM want to identify new market } \\
\text { opportunities and create real solutions that advance businesses, communities and } \\
\text { society in meaningful ways. }\end{array}$ \\
\hline $\begin{array}{l}\text { Idea Crossing: Innovation Challenge } \\
\text { [http://www.innovationchallenge.com/] }\end{array}$ & $\begin{array}{l}\text { The Innovation Challenge is the chance for MBA students to create an innovative } \\
\text { solution to a real-world challenge faced by the sponsors of the competition. The } \\
\text { teams research, brainstorm and present a unique concept to a global panel of } \\
\text { innovation though leaders and practitioners. }\end{array}$ \\
\hline $\begin{array}{l}\text { Initiative D21 (Siemens): Vison2Market } \\
\text { [http://www.initiatived21.de/english/ } \\
\text { lighthouse/vision2market.php] }\end{array}$ & $\begin{array}{l}\text { Coming up with innovative Products, Services or Processes. In three phases the best } \\
\text { ideas are chosen and then led through a test market with professional help and } \\
\text { financial support of respected coaches from economy, politics and society. }\end{array}$ \\
\hline $\begin{array}{l}\text { Motorola: Motofwrd } \\
\text { [http://promo.motorola.com/motofwrd/ } \\
\text { us/index.html] }\end{array}$ & $\begin{array}{l}\text { Create the Future of seamless mobility in a world without borders. Descriptions by } \\
\text { short stories (fiction), essay/white papers (non-fiction), (animated) short films, comic } \\
\text { strips or digital arts. }\end{array}$ \\
\hline $\begin{array}{l}\text { ThyssenKrupp: Formula Student Germany } \\
\text { [http://www.zukunft-technik-entdecken.de/] } \\
\text { [http://www.formulastudent.de/] }\end{array}$ & $\begin{array}{l}\text { Investment in the engineers of the future and support of Formula Students, an } \\
\text { international competition in which students design and build a racing car. Formula } \\
\text { Student challenges the team members to go the extra step in their education by } \\
\text { incorporating into it intensive experience in building and manufacturing as well as } \\
\text { considering the economic aspects of the automotive industry. }\end{array}$ \\
\hline $\begin{array}{l}\text { Unternehmertum: Innovation Competition } \\
\text { [http://www.unternehmertum.de/mobilitaet] }\end{array}$ & $\begin{array}{l}\text { Development of marketable ideas in the area of mobile information and } \\
\text { communication services, product and services to increase energy and time efficiency, } \\
\text { safety and comfort and new forms of mobility }\end{array}$ \\
\hline
\end{tabular}

Table 1: Selected examples of ideas competitions for students

The table shows that companies use ideas competitions for students in very different ways and with a wide variety of topics. To get a more specific picture of ideas competitions, the following section is analysing this phenomenon by its characteristics.

\subsubsection{Characteristics of ideas competitions}

As literature has not categorised ideas competitions yet, the following systematisation is derived from the analyses of current ideas competitions. Also, some characteristics from first research on idea competitions [37] are summarised in the following table 2: 


\begin{tabular}{|l|l|}
\hline Criteria & Characteristic values (Examples) \\
\hline Organizer & $\begin{array}{l}\text { Companies, Public Organisations, } \\
\text { Non-profit Organisations, Individuals }\end{array}$ \\
\hline Timeline & $\begin{array}{l}\text { Very Short (seconds / minutes), } \\
\text { Short (days), Middle (weeks), Long } \\
\text { Term (semester) }\end{array}$ \\
\hline Evaluation & Performance-oriented, Participation- \\
\hline Incentives & Money prizes, Non-cash prizes \\
\hline Context & Products, Processes \\
\hline $\begin{array}{l}\text { Problem } \\
\text { Specification }\end{array}$ & $\begin{array}{l}\text { High (Searching for a solution of a } \\
\text { specific problem), Low (General }\end{array}$ \\
\hline Elaborateness & Complexity, Quality, Condition \\
\hline Targeted Group & $\begin{array}{l}\text { Qualified (by age, interests), Not } \\
\text { Qualified }\end{array}$ \\
\hline $\begin{array}{l}\text { Composition of } \\
\text { groups }\end{array}$ & Single, Team \\
\hline $\begin{array}{l}\text { Idea reviewers } \\
\text { committee }\end{array}$ & $\begin{array}{l}\text { Specialists, Non-Professionals } \\
\text { (VIPs) }\end{array}$ \\
\hline Idea review & Person, Process, Context, Product \\
\hline $\begin{array}{l}\text { Nature of } \\
\text { Competition }\end{array}$ & Online, Offline, Mixed \\
\hline
\end{tabular}

Table 2: Criteria and characteristic values of ideas competition

The analysis of the idea competitions shows that, although a great diversity exists in the composition of the various components, several trends and best practices can be deduced.

The competition's organiser represents in most cases collaboration between an industry partner and an academic institution. Such partnerships are used to primarily target students as participants in the competitions. While some of these competitions only pursue the generation of ideas for innovation, a majority also have secondary objectives such as networking with students or fostering students' interest in specific industries or organisations.

For the target group of students, tasks are predominantly kept very generic, offering the participants a large solution space in which to submit their ideas. Although not required in most cases, students are offered the choice of participating in small groups with a faculty mentor. Submissions in the initial phases of idea competitions are limited to brief descriptions of ideas with lengths not exceeding four to five pages. Incentives for participation are comprised of cash prices of upwards of 1.000 Euro, but also extend to networking and job opportunities with the organising companies. Other incentives provide the participants with the opportunity to further develop their ideas in the frame of project and development support. Evaluations, with the exception of Crowdsourcing competitions, are carried out by juries, and the community rarely gets a chance to evaluate other submitted ideas.
The typical duration for an idea competition targeted at students is between four to 26 weeks.

Depending on how closely a competition is correlated to the primary business field of the organising company, the name and website will be integrated into the organiser's website or spun off with a separate website and name to develop an individual brand name for the competition.

\subsubsection{Working definition}

Based on the discussed characteristics, a working definition of an "ideas competition" is stated as follows:

An ideas competition is the invitation of a private or public organiser to a general public or a targeted group to submit contributions to a certain topic within a timeline. An ideareviewers committee evaluates these contributions and selects the rewarded winner(s) (Adapted from [37]).

\section{The Concept of the Ideas Competition}

After laying the theoretical groundwork by discussing innovation, virtual communities and ideas competitions, the following section presents an integrated concept of the ideas competition for the SAP UCC Community. Firstly, we analyse the motivation and interest of the stakeholders. Secondly, we plan the phases of the actual competition.

\subsection{Analysing Phase: Motivation and interests of Stakeholders}

In this section, the different interests and motivations of the competition's stakeholders are analysed. This is important because only with a concept that addresses every stakeholder a winwin situation emerges. The different stakeholders of the competition are derived from figure 2 and table 2: 1) Organiser, 2) Research \& Development Department, 3) Human Resources Department, 4) University Alliances Program, 5) Lecturers and 6) Students. Their motivation and interest structures are discussed as follows:

1. Organiser: The idea competition is organised by the research team of the project "SAP Community for Innovations". Their main interest is to find out how ideas competitions can help to scan and search the environment and strategically select innovative ideas out of a dispersed crowd of people. 
2. Research \& Development Department: Research and Development of the ERPcompany can receive innovative ideas from people dealing with the SAP software (but not as customers yet) without big effort in retrieving the information. To make sure that the ideas get used, they are defining interfaces to several research and product development groups within the company. The importance of innovative ideas is underlined by the statement of the firm's CEO: "What counts is the speed of transformation - and the business benefits of the new technologies. Innovativeness is the key factor in SAP's success“ " [17].

3. Human Resources Department: The motivation of the Human Resources Department is to identify the most promising students in this Virtual Community. By using the tool of an "ideas competition", which exhibits the phenomenon of self selection among the participating students, the Human Resources Department will find a) the more active students and b) students who do have a positive affinity to SAP as a product and firm.

4. University Alliances Program: The SAP University Alliances program provides university faculty members with the tools and resources necessary to teach students how technology can enable integrated business processes and strategic thinking -- and gives students the skills to add immediate value to the marketplace. Through the ideas competition, the program services for the SAP UCC User Group Community are enriched and activity within the User Group is fostered.

5. Lecturers: In general, this group of people has many teaching responsibilities at their educational institution and therefore tries to keep their commitment and time spent concerning SAP teaching as low as possible. Extrinsic motives for this group are free usage of UCCs' services (as the own educational institution pays for that) and the possibility to raise reputation within the User Group [22]. Content wise, they do have intrinsic motivation to learn about SAP products.

6. Students: The most heterogenic group of stakeholders are the students. They are dispersed over all educational institutions participating in the SAP Global University program. Their primary motivation is to get rewarded for their idea submitted to the competition. In addition, they do have the possibility to receive a better impression of SAP as a potential future employer.

\subsection{Planning Phase: A Concept of an integrated ideas competition}

3.2.1 Definition of characteristics. For the ideas competition, the following specifications of the characteristic values (based on section 2.2.2) are planned:

\begin{tabular}{|c|c|}
\hline Criteria & Specification of Characteristic \\
\hline Organizer & Public Organisation: Project "Community for Innovations" \\
\hline Timeline & Middle: 12 Weeks with 3 Phases \\
\hline Contest Phases & $\begin{array}{l}\text { Idea Submission: } 8 \text { weeks } \\
\text { Community Evaluation: } 2 \text { weeks } \\
\text { Jury Decision: } 2 \text { weeks } \\
\text { Weekly SkypeCasts on Ideas and Topics, e.g. "Web 2.0" }\end{array}$ \\
\hline Evaluation & Performance-oriented:Selection of best ideas by UCC, SAP UA and SAP Research \\
\hline Incentives & $\begin{array}{l}\text { Mixture of non-cash prizes and cash prizes: } \\
\text { Lecturers: - 1st:Gift Certificates for SAP UA Services / Software } \\
\text { - 1st-3rd: One SAP Consulting day } \\
\text { Students: } \\
\text { - 1st: } 2000 € \text { cash and SAP Training Week + SAP Certificate (worth } 12.000 € \text { ) } \\
\text { - 2nd-5th: } 200 € \text { cash and } 1 \text { UA UCC Training Week }\end{array}$ \\
\hline Context & $\begin{array}{l}\text { - new areas of application / new business segments } \\
\text { - new products / improvement of existing software }\end{array}$ \\
\hline Problem Specification & Middle: Explaining the context and problems customers do have. \\
\hline Elaborateness & $\begin{array}{l}\text { Complexity, Quality, Condition: The teams do have to provide an idea title, description, technological } \\
\text { background, benefit for the customer and an attachment for mockups / illustrations. }\end{array}$ \\
\hline Targeted Group & Qualified: Students and lecturers in the field of SAP Education \\
\hline Composition of groups & Team: At least one student together with his lecturer as mentor \\
\hline Idea reviewers committee & Specialists: Members of UCC, SAP UA and SAP Research \\
\hline Idea review & Process \& Product: Creativity, presentation, practicability \\
\hline Nature of Competition & Online: Providing an online platform to submit ideas \\
\hline
\end{tabular}

Table 3: The Ideas Competition: Specification of characteristics 
As we know from other ideas competitions, their key success factor is the incentive structure for the expected participants. Due to the need for mentoring, lecturers and their students are considered as one team in this setting. An online webpage is provided for all participants with relevant information about context (processes and products) and procedures of the competition. Additionally, lecturers receive course material for presentation in their classes. The planned process is described in the following section.

\subsubsection{Process of ideas competition and in-} tegration of stakeholders. The ideas competition is structured through the following process:

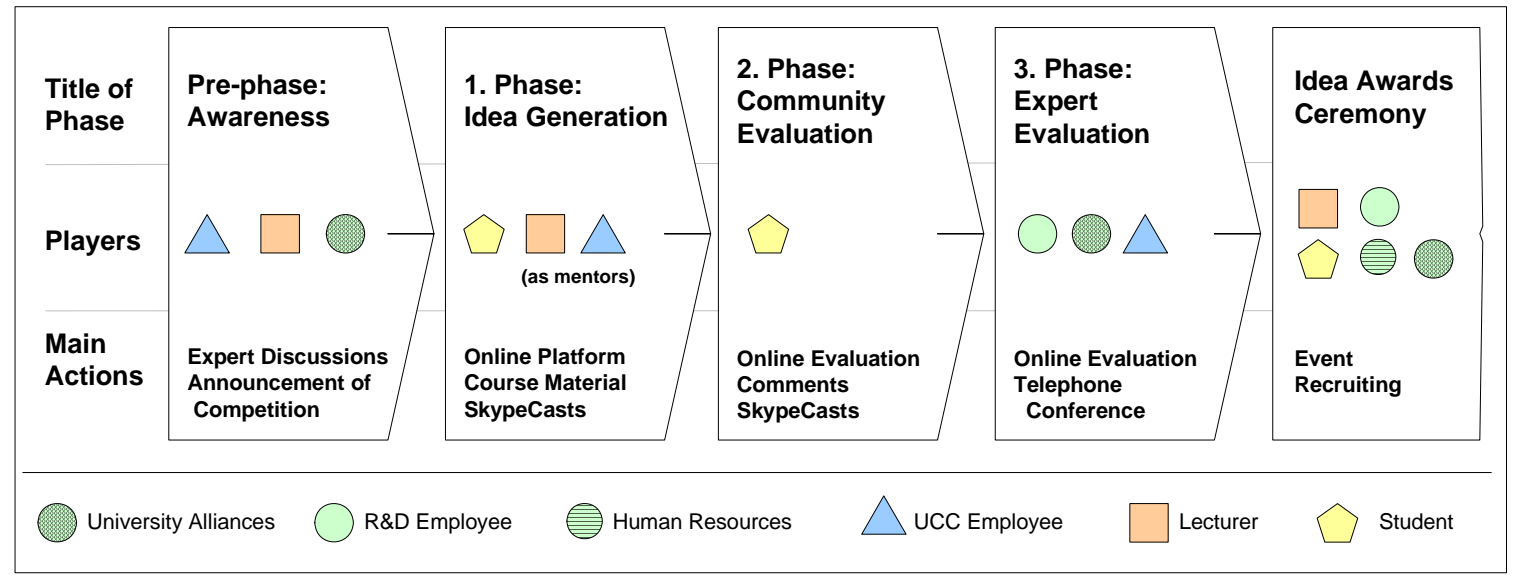

Figure 4: Process of ideas competition

Within the pre-phase, expert discussions took place with selected lecturers to make sure that this group of stakeholders (with "direct access" to their students) is involved at a very early stage of the process. Additionally, expectations and concerns could be addressed in a better way. The actual ideas competition was planned to start in the middle of the semester term with the idea generation, followed by students attending a class with a presentation held by the lecturer and getting access to the ideas competition online platform (http://www.SAPiens.info) to submit their ideas. After the submission phase, the ideas are to be reviewed by the assigned committee. A telephone conference will help to identify the three winning teams out of the 10 best-ranked teams. The 10 best-ranked teams will be invited to the Idea Awards Ceremony.

\section{The Implementation of the Ideas Competition}

This section provides a first insight on the still ongoing ideas competition:

"We are seeking for SAPiens - Masterminds who want to take part in designing the future of SAP and like to win great prices." [6]
Using this slogan the ideas competition started on April $30^{\text {th }} 2007$ with an initial E-Mail to all lecturers of the UCC Community. An information package was provided and the lecturers were asked to announce the competition within their ERP lessons. In follow-up, several communication tools (e.g., newsletters, E-Mails, telephone calls, SAP system notices, and postings at related student networking websites) were used to announce the ideas competition.

The competition website for the ideas submission phase is divided into four parts: 1) My SAPiens, 2) Community, 3) Communications and 4) Imprint. "My SAPiens“" provides the overview of the own submitted ideas and the profile of the registered user. Within the "Community" area, users can review and comment on ideas of other SAPiens and see a list of all ideas submitters. The "Communication" area includes a Chat function, moderated SkypeCasts (with SAP Experts) and a discussion forum, e.g., to address questions or search for new ideas. The "Imprint" section provides further information about the competition, e.g., main topics of idea submissions, prices, procedures and the jury.

Figure 5 shows the navigation of the website together with a list of submitted ideas: 


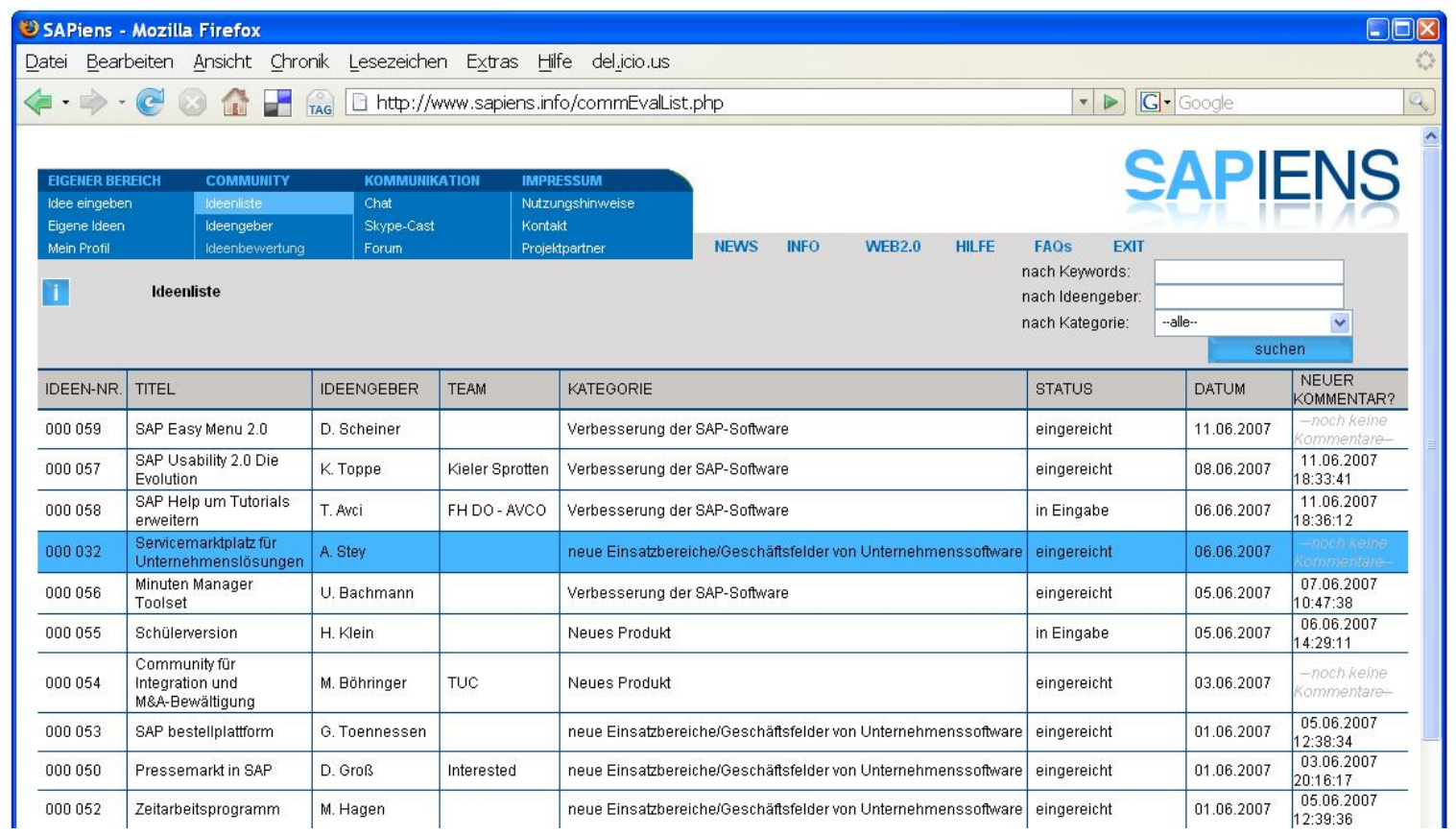

Figure 5: Website of the SAPiens Ideas Competition - List of Ideas

(Source: http://www.SAPiens.info, access date: 07/12/06)

\section{Conclusions and Outlook}

\subsection{Conclusions}

The following conclusions can be drawn by reviewing the theoretical background, the design of the ideas competition and the first feedback on implementation and usage behaviour:

- Integrating the concept of an ideas competition into VCs is a very promising approach for all stakeholders. The special characteristics of VCs, e.g., easy communication and coordination, do help to stimulate the ideas competition.

- From a managerial standpoint, one success factor has already emerged: It is very important to let all stakeholders participate at an early stage of the ideas competition development. This seems to be the best way to make sure that both motivations and interests of the stakeholders are addressed.

- The incentive structure for the participants of the ideas competition needs to be attractive, because this competition is not part of the students' required curriculum. Particularly students seek adequate motivation for their efforts spent in addition to their daily workload.
- Lessons learned from literature about open source projects show that firms do have serious problems in attracting, building and nurturing an external community for innovations (cp. [16], [38] \& [39]). Taking this issue into account, the concept of the ideas competition presented in this paper builds upon an already existing community and tries to stimulate more activity among the members of this community concerning communication and coordination.

From an operator's perspective, it is important that the main focus of the ideas competition is placed on the generation of innovative ideas for products and processes. Another underlying interest of the HR department stakeholder is the search and identification of the most promising students as future employees. Therefore, the wording and design of the information material and website could link into HR processes of the firm.

Going forward, it will be essential to elaborate mechanisms for supporting and harvesting the wisdom of crowds in selecting the best ideas. Furthermore, there is a conceptual gap between the generation and selection of ideas and their transformation into ultimate innovations. We need to explore further 
methods, concepts and tools to support the processing of ideas into innovations, also using the wisdom of crowds.

\subsection{Outlook}

In addition to the limitations of action research stated in section 2, further work should address (amongst others) the following open research questions:

- What are the implications for open innovation theory applying the concept of an "ideas competition"?

- What are the key lessons learned from "ideas competition" for the management of innovations within companies?

Also, this paper does not include empirical data of the ideas competition yet; the focus is on the analysis and planning phase. The evaluation of the online idea platform shown in section 4 and the interaction structures of SAPiens will also be part of further research. The actual contest will be finished at the end of June 2007. Therefore, we will be able to present further data and findings by the time of the conference.

\section{References}

[1] Balasubramanian, S. \& Mahajan, V. 2001. The Economic Leverage of the Virtual Community. International Journal of Electronic Commerce, 5(3): 103-138.

[2] Brunold, J., Merz, H., \& Wagner, J. 2000. www.cyber-communities.de - Virtual Communities: Strategie, Umsetzung, Erfolgsfaktoren. Landsberg/Lech: mi, Verlag Moderne Industrie.

[3] Bullinger, H.-J., Baumann, T., Fröschle, N., Mack, O., \& Trunzer, T. 2002. Business Communities. Bonn: Galileo Press.

[4] Chesbrough, H. W. 2003. Open Innovation: The New Imperative for Creating and Profiting from Technology (Hardcover). Harvard Business School Press Books: 1.

[5] Döring, N. 2003. Sozialpsychologie des Internet: die Bedeutung des Internet für

Kommunikationsprozesse, Identitäten, soziale Beziehungen und Gruppen (2 ed.). Göttingen [u.a.]: Hogrefe, Verl. für Psychologie.

[6] Ebner, W. 2007: SAPiens Ideas Competition of the UCC User Group Web: http://www.SAPiens.info, access date: 07/12/06.
[7] Ernst, H., Soll, J. H., \& Spann, M. 2004. Möglichkeiten der Lead User-Identifikation in OnlineMedien. In C. Herstatt (Ed.), Produktentwicklung mit virtuellen Communities: Kundenwünsche erfahren und Innovationen realisieren, 1 ed.: XI, 375 S. Wiesbaden: Gabler.

[8] Figallo, C. 1998. Tools, Techniques \& Trust. What makes a good virtual community? - Human and social perspectives. Paper presented at the First International Conference on Virtual Communities, Bath, UK.

[9] Franke, N. \& Piller, F. 2004. Value Creation by Toolkits for User Innovation and Design: The Case of the Watch Market. Journal of Product Innovation Management, 21(6): 401-415.

[10] Gailberger, M. 1999. Abschlußbericht zum Verbundvorhaben Ideenwettbewerb für Leitprojekte "Innovative Produkte": Master 2000

Konkretisierungsphase. Ulm: DaimlerChrysler, Forschungszentrum.

[11] Hazard, I. 2007. We > me. We are smarter than me. Web: http://www.wearesmarter.org, access date: 07/09/06.

[12] Hagel III, J. \& Armstrong, A. 1997. Net Gain Expanding markets through virtual communities. Wiesbaden: Thomas Gabler Verlag.

[13] Hermanns, R. 2001. Leben im Jahr 2020: studentischer Ideenwettbewerb; ein Gemeinschaftsprojekt des Ministeriums für Städtebau und Wohnen, Kultur und Sport des Landes NRW und der Energiesparagentur NRW. Aachen.

[14] Howe, J. 2006. 5 Rules of the New Labor Pool. In: WIRED, Vol. 06 (2006) Nr. 6, S. 180.

[15] Hummel, J. \& Lechner, U. 2002. Social Profiles of Virtual Communities. Paper presented at the 35th Annual Hawaii International Conference on System Sciences (HICSS'02), Big Island, Hawaii.

[16] Jeppesen, L. B. \& Frederiksen, L. 2006. Why Do Users Contribute to Firm-Hosted User Communities? The Case of Computer-Controlled Music Instruments. Organization Science, 17(1): 45.

[17] Kagermann, H. 2006. Editorial of magazine, SAP-Info: the magazine of the SAP Group, Vol. 2006: 3. Walldorf: SAP.

[18] Kim, A. J. 2000. Community building on the Web - secret strategies for successful online communities. Berkeley, Calif.: Peachpit. 
[19] Lau, F. 1997. A Review on the Use of Action Research in Information Systems Studies. In J. I. DeGross \& A. S. Lee \& J. Liebenau (Eds.), Information Systems and Qualitative Research: 31-68: Chapman \& Hall.

[20] Laubacher, R. 2006. MIT Center for Collective Intelligence. Web: http://cci.mit.edu, access date: 07/12/06.

[21] Leimeister, J. M. 2005. Virtuelle Communities für Patienten: Bedarfsgerechte Entwicklung, Einführung und Betrieb (1 ed.). Wiesbaden: Dt. Univ.Verl.

[22] Mohr, M., Wittges, H., Nicolescu, V., Krcmar, H., \& Schrader, H. 2006. Einbindung und Motivation informeller Multiplikatoren im IT-Training am Beispiel Education Service Providing. In H. Krcmar \& C. Rautenstrauch \& H. Wittges \& H. Schrader (Eds.), Wirtschaftsinformatik-Ausbildung mit SAP ${ }^{\circledR}$ Software: Reader zum Track der Multikonferenz Wirtschaftsinformatik 2006 in Passau, 1 ed.: 1-22. Lohmar: Eul.

[23] Piller, F. T. \& Walcher, D. 2006. Toolkits for idea competitions: a novel method to integrate users in new product development. R \& D Management, 36(3): 307.

[24] Preece, J. 2000. Online Communities - Designing Usability, Supporting Sociability. Chichester, New York, Weinheim, Brisbane, Singapore, Toronto: John Wiley and Sons.

[25] Prüfer, D. 2004. Ideen-Wettbewerb Bionik: Virotubes in Microsystems - Schlussbericht. Schmallenberg Hannover: Fraunhofer-Inst. f. Molekularbiologie u. Angewandte Ökologie.

[26] Rapoport, R. N. 1970. Three dilemmas in action research. Human Relations, 23(4): 499-513.

[27] Reichwald, R., Piller, F., \& Ihl, C. 2006. Interaktive Wertschöpfung : Open Innovation, Individualisierung und neue Formen der Arbeitsteilung (1 ed.). Wiesbaden: Gabler.

[28] Schrader, H. 2005. Früh übt sich. User Group Meeting des University-Alliances-Programms in Magdeburg. SAP INFO, 132.

[29] Surowiecki, J. 2005. The Wisdom of Crowds why the many are smarter than the few. New York: First Anchor Books Edition.

[30] Suthhof, A. 2005. Ideenwettbewerb zur Vorbereitung eines BMBF-Förderprogramms im Bereich Integriertes Wasserressourcen-Management (IWRM). Hannover: DLR, Internat. Büro des BMBF.
[31] Tidd, J., Bessant, J. R., \& Pavitt, K. 2005. Managing innovation: integrating technological, market and organizational change (3 ed.). Chichester [u.a.]: Wiley.

[32] Tseng, M. M. \& Piller, F. T. 2003. The customer centric enterprise: advances in mass customization and personalization. Berlin [u. a.] Springer-Verl.,.

[33] Ulrich, H. 1981. Die Betriebswirtschaftslehre als anwendungsorientierte Sozialwissenschaft. In M. N. Geist \& R. Köhler (Eds.), Die Führung des Betriebes. Festschrift für Curt Sandig: 1-26. Stuttgart: Poeschel Verlag.

[34] von Hippel, E. \& Katz, R. 2002. Shifting Innovation to Users via Toolkits. Management Science, 48(7): 821.

[35] von Hippel, E. 2005. Democratizing innovation. Cambridge, Mass. [u.a.]: MIT Press.

[36] Wagner, C.; Prasarnphanich 2007. Innovating Collaborative Content Creation: The Role of Altruism and Wiki Technology. In: Proceedings of the 40th Hawaii International Conference on System Sciences (HICSS 40), Big Island, Hawaii, January 3-6, 2007.

[37] Walcher, D. 2007. Der Ideenwettbewerb als Methode der aktiven Kundenintegration (1 ed.). Wiesbaden: Deutscher Universitäts-Verlag.

[38] West, J. \& O’Mahony, S. 2005. Contrasting Community Building in Sponsored and Community Founded Open Source Projects. Paper presented at the 38th Annual Hawai‘i International Conference on System Sciences.

[39] West, J. 2007. Value Capture and Value Networks in Open Source Vendor Strategies. Paper presented at the 40th Annual Hawaii International Conference on System Sciences (HICSS'07), Big Island, Hawaii. 